Research Article

\title{
Emulgel Formulation of Musa paradisiaca L. Peels
}

Formulasi Emulgel Kulit Buah Pisang Ambon (Musa paradisiaca L.)

Kimelvina, Suwaldi Martodihardjo, and Rina Kuswahyuning*

Faculty of Pharmacy, Universitas Gadjah Mada, Yogyakarta 55281 Indonesia

*Corresponding author: Rina Kuswahyuning | Email: rinakus@ugm.ac.id

Received: 8 August 2019; Revised: 22 August 2019; Accepted: 25 September 2019; Published: 29 September 2019

\begin{abstract}
The aim of this study was to utilize the peel of Ambon banana (Musa paradisiaca L.) to be formulated into emulgel topical preparation and to evaluate anti-radical activity and physical stability after 4 weeks of storage at room temperature. Ambon banana peel was processed into a juice, which was then concentrated through a freeze drying process. The results of freeze dried Ambon banana peel juice as much as $1 \%$ was formulated into an emulgel topical preparation. Freeze dried Ambon banana peel juice contained flavonoids of $52.71 \mu \mathrm{g}$, equivalent to quercetin/gram of fresh Ambon banana peel and had a radical scavenging activity value of 2,2-diphenyl-1-picrylhydrazyl (DPPH) with an IC50 of $65.6 \mu \mathrm{g} / \mathrm{mL}$. Emulgel freeze dried Ambon banana peel juice showed DPPH radical scavenging activity and this activity was stable for 4 weeks of storage at room temperature. Emulgel freeze dried Ambon banana peel juice did not undergo separation even though it was indicated that the droplet size changed significantly after storage. The viscosity of the emulgel increased significantly, while the dispersibility and adhesion of the emulgel showed a significant decrease after storage.
\end{abstract}

Keywords : banana peel; emulgel; antioxidant

\begin{abstract}
Abstrak: Penelitian ini bertujuan memanfaatkan limbah kulit buah pisang ambon (Musa paradisiaca L.) untuk diformulasikan menjadi sediaan topikal emulgel dan mengevaluasi aktivitas antiradikal dan stabilitas fisik setelah 4 minggu penyimpanan pada suhu ruang. Kulit buah pisang ambon diolah menjadi jus yang kemudian dipekatkan melalui proses freeze drying. Hasil freeze dried jus kulit buah pisang ambon sebanyak $1 \%$ diformulasikan menjadi sediaan topikal emulgel. Freeze dried jus kulit buah pisang ambon mengandung flavonoid sebesar 52,71 $\mu \mathrm{g}$ ekuivalen kuersetin/gram kulit pisang ambon segar dan memiliki nilai aktivitas penangkapan radikal 2,2-diphenyl-1-picrylhydrazyl (DPPH) dengan IC 50 65,6 $\mu \mathrm{g} / \mathrm{mL}$. Emulgel freeze dried jus kulit buah pisang ambon menujukkan aktivitas penangkapan radikal DPPH dan aktivitas ini stabil selama 4 minggu penyimpanan pada suhu ruang. Emulgel freeze dried jus kulit buah pisang ambon tidak mengalami pemisahan meskipun terindikasi mengalami perubahan ukuran droplet setelah penyimpanan. Viskositas emulgel mengalami peningkatan secara signifikan, sedangkan daya sebar dan daya lekat emulgel menunjukkan penurunan yang signifikan setelah penyimpanan.
\end{abstract}

Kata kunci : kulit buah pisang ambon; emulgel; antioksidan 


\section{PENDAHULUAN}

Penggunaan antioksidan topikal berpotensi mampu melindungi kulit dari pengaruh sinar ultraviolet (UV). Salah satu sumber antioksidan diketahui berasal dari buah-buahan, salah satunya adalah buah pisang [1]. Umumnya masyarakat luas mengonsumsi bagian daging dari buah pisang saja, sedangkan kulitnya sering dibuang dan belum dimanfaatkan secara optimal. Saat ini, telah banyak penelitian mengemukakan bahwa aktivitas antioksidan kulit pisang lebih tinggi dibandingkan buahnya [2-5].

Kulit pisang diketahui mengandung senyawa fitokimia seperti senyawa fenolik, flavonoid, karotenoid, dan galoketekin [6]. Jenis pisang sangat mempengaruhi aktivitas antioksidannya. Aktivitas penangkapan radikal DPPH dari ekstrak air kulit pisang Musa paradisiaca (pisang ambon) diketahui lebih tinggi daripada Musa sinesis [5]. Analisis kandungan fitokimia menunjukkan Musa paradisiaca memiliki kandungan total fenolik sebesar $83,32 \pm 4,38 \mathrm{mg} / \mathrm{g}$ (ekuivalen asam galat) dan flavonoid sebesar 17,64 $\pm 3,01 \mathrm{mg} / \mathrm{g}$ (ekuivalen kuersetin). Kandungan senyawa-senyawa ini terdeteksi dalam jumlah yang jauh lebih kecil pada Musa sinensis.

Penelitian ini memanfaatkan limbah kulit dari buah pisang yang banyak dikonsumsi masyarakat yaitu pisang ambon (Musa paradisiaca L.). Meskipun penelitian tentang aktivitas antioksidan kulit pisang ambon (Musa paradisiaca L.) telah dilaporkan [7-9], namun pemanfaatannya ke dalam bentuk sediaan topikal emulgel belum diteliti. Pada penelitian ini, freeze dried jus kulit pisang ambon diteliti aktivitas penngkapan radikal 2,2-diphenyl-1-picrylhydrazyl (DPPH) dan selanjutkan diformulasikan ke dalam bentuk emulgel. Emulgel freeze dried jus kulit pisang ambon dievaluasi sifat fisik sebelum dan setelah penyimpanan pada suhu ruang $\left(28 \pm 2^{\circ} \mathrm{C}\right)$ selama 4 minggu. Selain itu, aktivitas penangkapan radikal DPPH pada emulgel ekstrak kulit pisang juga akan diteliti.

\section{BAHAN DAN METODE}

\subsection{Bahan}

Bahan yang digunakan dalam penelitian ini adalah kulit buah pisang ambon matang (diperoleh dari daerah Sleman, Yogyakarta). Radikal 2,2-diphenyl-1-picrylhydrazyl (DPPH) (p.a.), kuersetin (p.a.), dan asam askorbat (p.a.) diperoleh dari Sigma. Metanol (p.a.) diperoleh dari E-Merck. Bahan-bahan Polietilen glikol (PEG) 400, asam oleat, propilen glikol, Croduret 50 ss, Span 80, Carbopol, trietanolamin (TEA), Tween 80 berderajad farmasetis.

\subsection{Identifikasi tanaman}

Buah pisang ambon matang yang diperoleh dari daerah Sleman, Yogyakarta, diidentifikasi terlebih dahulu untuk mengetahui identitas tanaman di Depatermen Biologi Fakultas Farmasi Universitas Gadjah Mada.

\subsection{Pembuatan freeze dried jus kulit buah pisang ambon}

Buah pisang ambon dibersihkan dari kotoran yang menempel pada kulit buahnya dengan air mengalir, kemudian kulit dikupas, kulit pisang dipotong-potong kecil berbentuk kubus $( \pm 1 \mathrm{~cm})$ dan ditimbang sebanyak \pm 600 gram. Kulit pisang direndam dengan larutan asam sitrat selama 15 menit untuk mengurangi reaksi pencoklatan pada kulit pisang. Terlebih dahulu dilakukan orientasi perendaman kulit pisang ambon dalam larutan asam sitrat dengan konsentrasi berbeda $(2-10 \%)$, konsentrasi yang digunakan dilihat dari hasil rendaman yang efektif mencegah browning kulit pisang ambon. Setelah itu ditiriskan dan dihaluskan dengan menggunakan blender dengan penambahan air sebanyak 1/6 dari bobot kulit pisang segar. Hasil disaring dengan kain saring 
kemudian dipekatkan dengan freeze dryer (Labconco, Missouri) selama 24 jam dengan suhu freezer $-42^{\circ} \mathrm{C}$ dan pengering vakum (tekanan ruangan sublimasi sekitar $0,0025 \mathrm{bar}$ ) dengan suhu mencapai $38^{\circ} \mathrm{C}$

\subsection{Pengukuran kandungan flavonoid kulit pisang ambon}

Kandungan flavonoid freeze dried kulit buah pisang ambon ditentukan dengan metode kolorimetri [10]. Sebanyak $1 \mathrm{ml}$ larutan freeze dried jus kulit pisang ambon (1\%) dimasukkan ke dalam labu takar 5,0 mL, ditambah 1,5 mL metanol, 0,1 mL alumunium klorida 10\%, dan 0,1 $\mathrm{mL} 1$ $\mathrm{M}$ natrium asetat. Kemudian ditambah air suling hingga volume 5,0 $\mathrm{mL}$, lalu diukur absorbansinya pada panjang gelombang $436 \mathrm{~nm}$ dengan waktu optimum pembacaan dari menit ke-35 hingga menit ke-50. Kurva larutan kuersetin kadar 4, 8, 12, 16, dan $20 \mu \mathrm{g} / \mathrm{mL}$ dibuat dan diuji dengan perlakuan yang sama. Kandungan flavonoid dinyatakan ekuivalen kuersetin dalam $\mu \mathrm{g} / \mathrm{g}$ kulit pisang ambon segar.

\subsection{Pengukuran aktivitas antiradikal freeze dried kulit buah pisang ambon}

Aktivitas antioksidan freeze dried jus kulit buah pisang ambon ditentukan dengan metode penangkapan radikal DPPH [11]. Sebanyak $3 \mathrm{~mL}$ larutan seri kadar 20, 40, 60, 80, dan $100 \mu \mathrm{g} / \mathrm{mL}$ freeze dried jus kulit pisang ambon masing-masing dimasukkan dalam labu takar $5 \mathrm{~mL}$, lalu ditambahkan $1 \mathrm{~mL}$ larutan DPPH 0,4 mM dan dicukupkan volumenya dengan metanol p.a hingga $5 \mathrm{~mL}$. Pengukuran serapan dilakukan pada waktu optimum pembacaan 30 menit dan panjang gelombang maksimum $(516 \mathrm{~nm})$ menggunakan spektrofotometer UV-Vis. Untuk pembanding aktivitas penangkapan radikal DPPH digunakan asam askorbat dan kuersetin. Kurva baku seri baku larutan asam askorbat adalah $1-5 \mu \mathrm{g} / \mathrm{mL}$ dan larutan kuersetin adalah 0,3-3,0 $\mu \mathrm{g} / \mathrm{mL}$. Aktivitas antioksidan freeze dried jus kulit pisang ambon dan larutan baku dihitung nilai $\mathrm{IC}_{50}$ dengan menggunakan persamaan regresi linier dimana konsentrasi sampel sebagai sumbu $x$ dan persen inhibisi sebagai sumbu y. Besarnya \% inhibisi dihitung dengan rumus sebagai berikut (dimana Ao merupakan absorbansi campuran reaksi DPPH yang tidak mengandung freeze dried kulit pisang dan $A_{1}$ merupakan absorbansi larutan uji:

$$
\text { Aktivitas penangkapan radikal DPPH }(\%)=\frac{A 0-A 1}{A 0} \times 100
$$

\subsection{Formulasi emulgel}

Pembuatan emulsi primer A/M dengan larutan PEG 400-HCl 0,1\% sebagai fase air yang akan melarutkan hasil freeze dried jus kulit pisang sebanyak 1\%. Freeze dried kulit buah pisang ambon yang telah larut ditambahkan asam benzoat $0,1 \%$ dan propilen glikol. Fase minyak yang digunakan ialah asam oleat dan emulgatornya berupa kombinasi dari span 80 dan croduret 50 yang dicampur dengan cara diaduk dengan stirrer pada kecepatan 1000 rpm selama 5 menit [12]. Pembuatan emulsi air dalam minyak dengan cara menuangkan fase air sedikit demi sedikit ke dalam campuran fase minyak dan emulgator, diaduk dengan kecepatan $1500 \mathrm{rpm}$ selama 20 menit pada suhu kamar. Selanjutnya carbopol didispersikan dengan dapar sitrat $\mathrm{pH}$ 5,4 dibantu dengan penambahan pembasah TEA sedikit demi sedikit dengan kecepatan pengadukan 750 rpm sampai gel mengembang dan jernih. Gel yang terbentuk ditambahkan tween 80 dan didispersikan emulsi primer ke dalam basis gel sedikit demi sedikit hingga terbentuk emulgel dengan stirrer kecepatan pengadukan $500 \mathrm{rpm}$ selama 15 menit. Formula emulgel freeze dried kulit pisang ambon dapat dilihat pada Tabel 1. 
Tabel 1. Formula emulgel freeze dried kulit pisang ambon

\begin{tabular}{lc}
\hline Bahan & Komposisi (\%) \\
\hline Freeze dried kulit pisang ambon & 1 \\
PEG 400-HCl 0,1\% (3:1) & 12 \\
Asam benzoat & 0,1 \\
Span 80 & 2 \\
Croduret 50 & 4 \\
Propilen glikol & 2 \\
Asam oleat & 18,9 \\
Carbopol & 1,25 \\
TEA & 1,25 \\
Tween 80 & 1,5 \\
Dapar sitrat pH 5,4 & 56 \\
\hline
\end{tabular}

\subsection{Uji aktivitas antiradikal freeze dried jus kulit buah pisang ambon dalam sediaan emulgel}

Sebanyak 0,3 gram emulgel 1\% dan dilarutkan dalam $10 \mathrm{~mL}$ metanol p.a., lalu divorteks selama 15 menit dan disaring. Filtrat diambil $500 \mu \mathrm{L}$ dimasukkan ke labu takar $5 \mathrm{~mL}$, ditambahkan $1 \mathrm{~mL}$ larutan DPPH 0,4 mM, dan dicukupkan volumenya dengan metanol p.a hingga $5 \mathrm{~mL}$. Pengukuran serapan dilakukan pada panjang gelombang maksimum DPPH menggunakan spektrofotometer UV-Vis. Emulgel tanpa mengandung hasil freeze dried jus kulit pisang digunakan sebagai kontrol negatif dan dikerjakan sama seperti emulgel yang mengandung freeze dried jus kulit pisang.

\subsection{Evaluasi sifat fisik emulgel}

Parameter uji stabilitas fisik emulgel antara lain pengamatan organoleptis (bentuk, warna, dan bau), pengukuran luas globul menggunakan mikroskop (dengan bantuan pewarna gentian violet dan mengambil 20 partikel globul secara acak), pengukuran viskositas (dengan alat viskometer rion spindle nomor 1), pengukuran $\mathrm{pH}$ [13], pengujian daya sebar, dan pengujian daya lekat pada hari ke-1 dan 28 pada suhu ruang $\left(28 \pm 2^{\circ} \mathrm{C}\right)$.

\subsection{Analisis data}

Signifikansi perbedaan stabilitas sifat fisik emulgel freeze dried jus kulit buah pisang ambon setelah 4 minggu penyimpanan diuji menggunakan analisis statistik SPSS menggunakan paired samples $T$ test.

\section{HASIL DAN PEMBAHASAN}

\subsection{Identifikasi tanaman}

Hasil identifikasi kebenaran identitas tanaman yang digunakan dalam penelitian diperoleh bahwa nama tanaman pisang ambon yang digunakan dalam penelitian adalah Musa paradisiaca L.

\subsection{Pembuatan freeze dried jus kulit buah pisang ambon}

Orientasi kadar larutan asam sitrat diperoleh bahwa pada kadar asam sitrat $8 \%$ efektif dalam mengurangi reaksi pencoklatan jus kulit pisang ambon. Jus kulit pisang ambon sesudah di-freeze dried (Gambar 1) menghasilkan 21,66 gram bobot kering yang memiliki tekstur yang sangat 
kenyal dan berwarna coklat. Bobot awal kulit pisang segar sebelum di-freeze dried sebanyak 553,79 gram, sehingga dapat dihitung randemen jus kulit pisang ambon ialah sebesar 3,79\%. Hasil freeze dried jus kulit buah pisang disimpan di dalam desikator berisi silika gel aktif selama penyimpanan.



Gambar 1. Hasil freeze dried jus kulit buah pisang ambon

\subsection{Pengukuran kandungan flavonoid kulit pisang ambon}

Penentuan kadar flavonoid jus kulit pisang ambon sebelum dan sesudah freeze drying dilakukan menggunakan metode kolorimetri. Hubungan antara konsentrasi kuersetin (4,07-12,20 $\mu \mathrm{g} / \mathrm{mL}$ ) dan absorbansi diperoleh persamaan regresi linier $\mathrm{y}=0,0834 \mathrm{x}-0,1308$ dengan harga koefisien korelasi $\left(R^{2}\right)$ 0,999. Kadar flavonoid rata-rata hasil freeze dried jus kulit pisang ambon mengandung 52,71 $\mu \mathrm{g} / \mathrm{gram}$. Hasil ini jauh lebih kecil dari hasil penelitian Oyeyinka dan Afolayan (5), yang melaporkan bahwa ekstrak air kulit pisang M. paradisiaca mengandung flavonoid sebesar $17,64 \pm 3,01 \mathrm{mg} / \mathrm{g}$. Perbedaan seperti sumber tanaman dan kondisi ekstraksi dapat mempengaruhi hasil ini [14].

\subsection{Pengukuran aktivitas antiradikal freeze dried kulit buah pisang ambon}

Pengujian aktivitas antiradikal DPPH hasil freeze dried kulit pisang ambon tersaji pada Tabel 2. Nilai IC $_{50}$ freeze dried jus kulit pisang ambon yaitu sebesar $65,6 \mu \mathrm{g} / \mathrm{mL}$. Hasil ini lebih rendah dibandingkan dengan $\mathrm{IC}_{50} 40 \mu \mathrm{g} / \mathrm{mL}$ ekstrak air kulit pisang ambon hasil penelitian Oyeyinka dan Afolayan (5), Prasetya (15) yang menemukan nilai IC 50 sebesar 2350,3 $\mu \mathrm{g} / \mathrm{mL}$ dari ekstrak kulit pisang ambon kuning. Nilai IC 50 menunjukkan konsentrasi larutan sampel yang dibutuhkan untuk mereduksi radikal DPPH sebesar 50\%. Semakin kecil nilai IC 50 maka semakin tinggi potensi aktivitas penangkapan radikal bebas, sehingga dapat dikatakan bahwa potensi kulit pisang ambon dalam penangkapan radikal DPPH lebih besar dibandingkan kulit pisang ambon kuning. Suatu senyawa dikatakan memiliki aktivitas antioksidan kelompok kuat jika nilai IC 50 antara 50-100 $\mu \mathrm{g} / \mathrm{mL}$ [16]. Hal ini berarti freeze dried jus kulit pisang ambon memiliki aktivitas antioksidan yang kuat. Nilai IC $_{50}$ penangkapan radikal DPPH kuersetin dan asam askorbat sebagai pembanding menunjukkan hasil masing-masing yaitu 2,7 $\mu \mathrm{g} / \mathrm{mL}$ dan 2,2 $\mu \mathrm{g} / \mathrm{mL}$. Aktivitas antiradikal freeze dried jus kulit pisang ambon masing-masing 1/24 dan 1/29 kali lebih lemah dibandingkan kuersetin dan asam askorbat. Hasil yang serupa juga dilaporkan oleh Oyeyinka dan Afolayan (5), yang menunjukkan bahwa nilai IC 50 aktivitas penangkapan radikal DPPH ekstrak air kulit pisang $M$. paradisiaca lebih kecil ( $\mathrm{IC}_{50} 40 \mu \mathrm{g} / \mathrm{mL}$ ) dibandingkan asam galat ( $\mathrm{IC}_{50} 1 \mu \mathrm{g} / \mathrm{mL}$ ) ataupun rutin (IC $\mathrm{C}_{50} 10$ $\mu \mathrm{g} / \mathrm{mL})$. 
Tabel 2. Hasil pengujian aktivitas penangkapan radikal DPPH freeze dried kulit pisang

\begin{tabular}{cc}
\hline Kadar freeze dried kulit pisang $(\mu \mathrm{g} / \mathrm{mL})$ & $\begin{array}{c}\text { Aktivitas penangkapan radikal DPPH } \\
\text { (Rerata } \pm \text { simpangan baku) }\end{array}$ \\
\hline 1 & $13,9 \pm 2,3$ \\
10 & $22,4 \pm 1,2$ \\
40 & $36,5 \pm 3,8$ \\
70 & $56,1 \pm 4,0$ \\
100 & $65,2 \pm 1,3$ \\
\hline
\end{tabular}

Selain menunjukkan aktivitas antioksidan dengan pengujian radikal DPPH, ekstrak air kulit pisang $M$. paradisiaca juga menunjukkan aktivitas antioksidannya dengan metode pengujian ABTS (2,2'-azino-bis(3-ethylbenzothiazoline-6-sulphonic acid)) dan FRAP (ferric reducing antioxidant power). Ekstrak air kulit pisang M. paradisiaca dilaporkan mengandung senyawa total fenolik dan flavonoid yang bertanggung jawab terhadap aktivitas penangkapan radikal DPPH nya [5]. Kaitan antara kandungan total fenolik dalam ekstrak kulit psiang dengan aktivitas penangkapan radikal DPPH juga telah dilaporkan untuk kulit pisang Raja, Berangan, dan Mas [17].

\subsection{Formulasi emulgel}

Penampakan hasil formulasi emulgel dan basis emulgel tanpa bahan aktif dapat dilihat pada Gambar 2. Pengamatan organoleptis sediaan emulgel sebelum dan setelah penyimpanan selama 4 minggu memiliki karakterisitik seperti pada Tabel 3. Hasil organoleptis menunjukkan adanya sedikit perubahan warna emulgel freeze dried kulit pisang ambon setelah disimpan selama 28 hari pada suhu ruangan $\left(28 \pm 2^{\circ} \mathrm{C}\right)$. Kemungkinan senyawa fenolik dalam ekstrak air kulit pisang dapat mengalami oksidasi yang menyebabkan berwarna kecoklatan [18]. Hasil evaluasi karakteristik fisik gel sebelum dan setelah 4 minggu penyimpanan pada suhu ruang masing-masing tersaji pada Tabel 4 dan 5 .
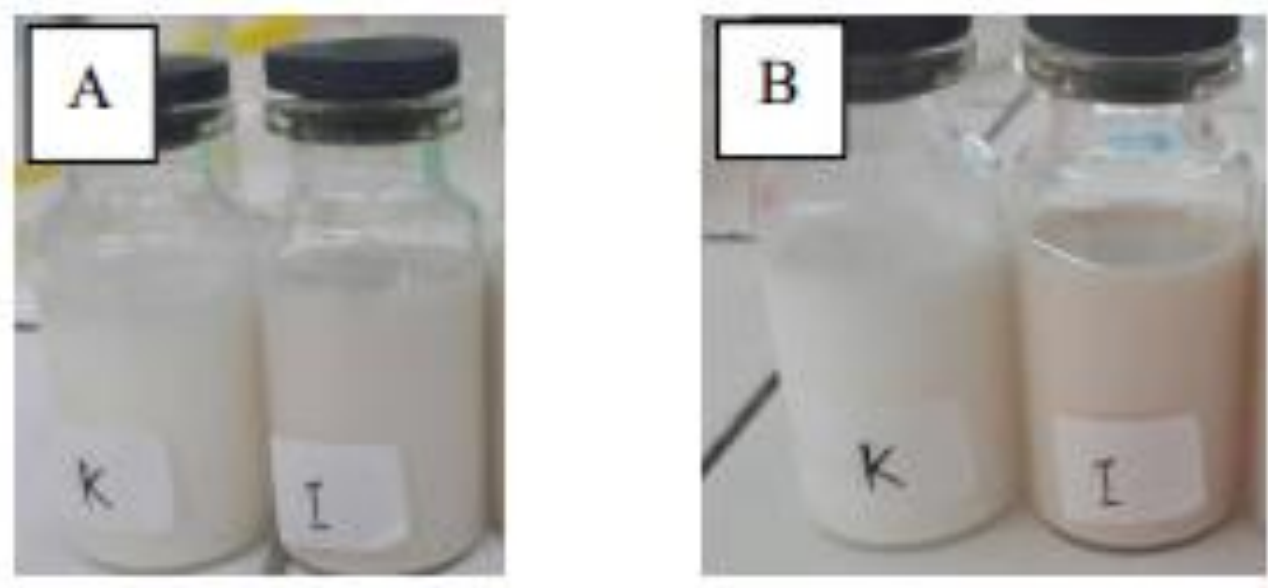

Gambar 2. Hasil emulgel freeze dried jus kulit pisang ambon hari-1 (A) dan hari-28 (B), dimana K adalah basis emulgel dan I merupakan emulgel freeze dried kulit pisang ambon 
Tabel 3. Pengamatan organoleptis emulgel freeze dried kulit pisang sebelum dan setelah 4 minggu penyimpanan pada suhu ruang $\left(28 \pm 2^{\circ} \mathrm{C}\right)$

\begin{tabular}{lll}
\hline Organoleptis & Hari ke-1 & Hari ke-28 \\
\hline Bau & Khas & Khas \\
Warna & Putih-coklat muda & Putih-coklat tua \\
Tekstur & Terasa halus \& tidak lengket & Terasa halus \& tidak lengket \\
\hline
\end{tabular}

Tabel 4. Karakteristik emulgel freeze dried kulit pisang ambon dan basis emulgel

\begin{tabular}{|c|c|c|c|c|c|}
\hline & $\begin{array}{c}\text { Ukuran } \\
\text { globul }\left(\mu \mathrm{m}^{2}\right)\end{array}$ & $\begin{array}{c}\text { Viskositas } \\
\text { (dPas) }\end{array}$ & $\mathrm{pH}$ & Daya sebar $(\mathrm{cm})$ & Waktu lekat (detik) \\
\hline Emulgel & $145,1 \pm 9,2$ & $36,2 \pm 2,9$ & $5,07 \pm 0,21$ & $5,93 \pm 0,28$ & $2,33 \pm 0,22$ \\
\hline Basis emulgel & $146,9 \pm 19,6$ & $40,4 \pm 1,5$ & $5,87 \pm 0,09$ & $6,64 \pm 0,11$ & $2,19 \pm 0,58$ \\
\hline
\end{tabular}

Tabel 5. Karakteristik emulgel freeze dried kulit pisang ambon dan basis emulgel setelah 4 minggu penyimpanan pada suhu ruang $\left(28 \pm 2^{\circ} \mathrm{C}\right)$

\begin{tabular}{|c|c|c|c|c|c|}
\hline & $\begin{array}{l}\text { Ukuran } \\
\text { globul }\left(\mu \mathrm{m}^{2}\right)\end{array}$ & $\begin{array}{l}\text { Viskositas } \\
\text { (dPas) }\end{array}$ & $\mathrm{pH}$ & Daya sebar $(\mathrm{cm})$ & Waktu lekat (detik) \\
\hline Emulgel & $172,0 \pm 11,8$ & $52,8 \pm 4,8$ & $5,11 \pm 0,1$ & $6,10 \pm 0,29$ & $1,66 \pm 0,41$ \\
\hline Basis emulgel & $176,1 \pm 13,5$ & $58,2 \pm 4,1$ & $5,68 \pm 0,2$ & $6,45 \pm 0,20$ & $0,99 \pm 0,48$ \\
\hline
\end{tabular}
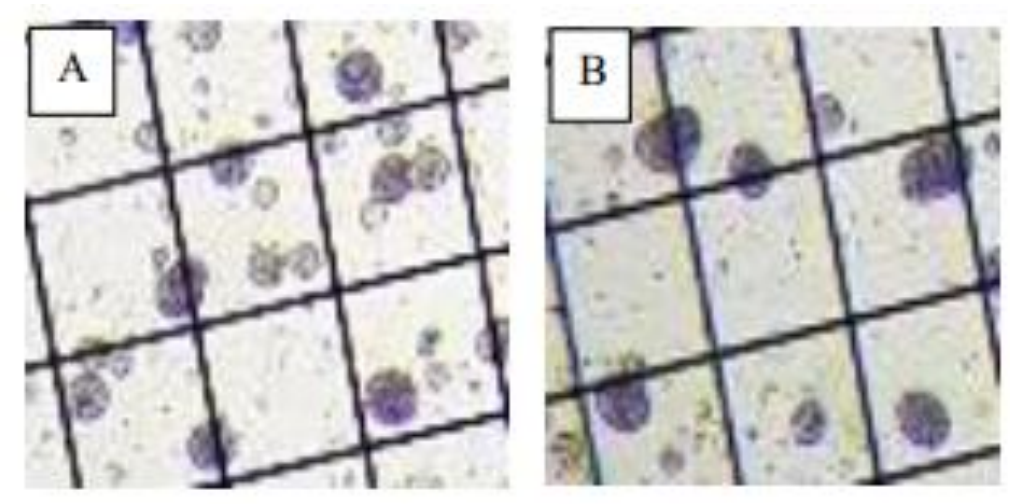

Gambar 3. Tampilan mikroskopik emulgel freeze dried jus kulit buah pisang ambon hari ke1 (A) dan hari-28 (B) dengan pewarnaan gentian violet pada fase air (perbesaran 4 kali)

Penampakan visual perubahan ukuran globul emulgel pada hari ke-1 dan ke-28 dapat dilihat pada Gambar 3. Evaluasi ukuran globul mencerminkan kualitas dan stabilitas sediaan emulsi [19, 20]. Hasil pengukuran globul emulgel menunjukkan bahwa semakin lama penyimpanan, terjadi perubahan ukuran globul emulgel menjadi lebih besar. Analisis statistik perubahan ukuran luas globul emulgel kontrol dan emulgel uji selama 4 minggu menunjukkan adanya perbedaan signifikan ukuran luas globul pada emulgel uji pada hari ke-28. Peningkatan ukuran globul diduga disebabkan karena pengaruh emulgator yang kurang mampu menurunkan tegangan permukaan sehingga partikel minyak cenderung akan bersatu membentuk globul minyak. Selain itu, viskositas emulgel juga dapat mempengaruhi stabilitas ukuran droplet. Peningkatan ukuran droplet selama penyimpanan dapat disebabkan karena viskositas emulgel kurang mampu menahan koalesensi droplet selama penyimpanan [21]. Peningkatan ukuran globul setelah uji stabilitas juga dilaporkan terjadi pada emulsi ekstrak soybean [19]. 
3.6. Uji aktivitas antiradikal freeze dried jus kulit buah pisang ambon dalam sediaan emulgel

Evaluasi aktivitas antiradikal emulgel freeze dried jus kulit pisang ambon didapatkan hasil penangkapan radikal DPPH sebesar $26,7 \pm 8,4 \%$, sedangkan setelah penyimpanan selama 4 minggu

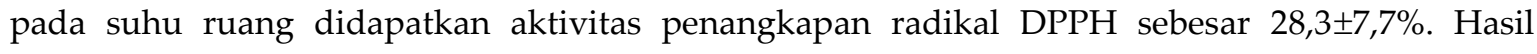
analisis statistika diperoleh bahwa perubahan aktivitas antiradikal dari emulgel freeze dried kulit pisang ambon tidak berbeda signifikan. Aktivitas penangkapan radikal DPPH ekstrak kulit pisang dapat dipertahankan dalam sediaan emulgel selama penyimpanan. Hasil uji stabilitas penangkapan radikal emulgel freeze dried kulit pisang ini serupa dengan hasil studi yang lain yang melaporkan bahwa antioksidan relatif stabil disimpan pada suhu ruang [13, 24]. Evaluasi fungsional antioksidan dalam formula topikal merupakan bagian yang sangat penting dalam pengembangan sediaan topikal untuk aktivitas antioksidan [13].

\subsection{Evaluasi sifat fisik emulgel}

Hasil uji viskositas emulgel kulit pisang ambon menggambarkan adanya peningkatan viskositas selama 4 minggu penyimpanan dalam suhu ruang. Idealnya viskositas sediaan tidak berubah selama penyimpanan maupun saat digunakan. Banyak faktor yang dapat mempengaruhi viskositas suatu sediaan emulgel, seperti faktor pencampuran atau pengadukan saat membuat emulsi, faktor pemilihan surfaktan, zat pengental, ukuran partikel dispersi, dan proporsi fase pada sifat aliran yang diperoleh. Analisis statistika perubahan viskositas selama penyimpanan 4 minggu dalam suhu ruang $\left(28 \pm 2^{\circ} \mathrm{C}\right)$ menunjukkan perubahan signifikan baik pada basis emulgel maupun emulgel kulit buah pisang. Hal ini kemungkinan disebabkan karena gelling agent Carbopol dan konsentrasi yang digunakan dalam formula tidak cukup menahan keluarnya air dari emulgel selama penyimpanan (sineresis) [22]. Hal ini dapat menyebabkan peningkatan viskositas.

Hasil pengukuran $\mathrm{pH}$ emulgel baik kontrol maupun uji telah sesuai dengan $\mathrm{pH}$ kulit manusia, yaitu antara 4,5-7,0 [23]. Nilai pH tidak boleh terlalu asam karena dapat menyebabkan iritasi pada kulit. Dari analisis paired samples $T$ test perbandingan $\mathrm{pH}$ hari ke-1 dan ke-28 diperoleh pH emulgel uji tidak berbeda signifikan ( $>>0,05)$. Kestabilan $\mathrm{pH}$ merupakan salah satu parameter penting yang menentukan stabil atau tidaknya suatu sediaan, sehingga didapatkan bahwa $\mathrm{pH}$ sediaan emulgel freeze dried jus kulit pisang ambon stabil selama penyimpanan.

Emulgel kulit pisang ambon memiliki daya sebar 5-7 cm dan terlihat adanya penurunan ukuran diameter emulgel setelah 4 minggu penyimpanan dalam suhu kamar. Hasil ini berhubungan dengan peningkatan viskositas emulgel setelah penyimpanan. Semakin tinggi viskositas emulgel maka semakin turun daya peyebarannya, begitu pula sebaliknya. Meskipun demikian, perbedaan perubahan daya sebar emulgel antara hari ke-1 dan hari ke-28 menunjukkan nilai tidak signifikan $(p>0,05)$. Pengujian daya lekat emulgel selama 4 minggu penyimpanan menunjukkan adanya penurunan waktu lekat pada hari ke-28. Hasil analisis statistik menunjukkan adanya penurunan daya lekat yang signifikan pada emulgel jus kulit pisang ambon $(p<0,05)$ setelah penyimpanan.

\section{KESIMPULAN}

Hasil freeze dried jus kulit buah pisang ambon mengandung flavonoid sebesar 52,71 $\mu \mathrm{g}$ ekuivalen kuersetin/gram kulit pisang ambon segar dan memiliki nilai IC 50 65,6 $\mu \mathrm{g} / \mathrm{mL}$. Emulgel kulit pisang mengalami peningkatan ukuran globul dan viskositas yang siginifkan selama 
penyimpanan pada suhu ruang selama 4 minggu. Aktivitas penangkapan radikal DPPH emulgel kulit pisang dapat dipertahankan selama waktu penyimpanan pada suhu ruang $\left(28 \pm 2^{\circ} \mathrm{C}\right)$.

\section{Ucapan Terima Kasih: -}

\section{Konflik Kepentingan: -}

\section{Reference}

1. Someya, S., Yoshiki, Y., Okubo, K., Antioxidant compounds from bananas (Musa Cavendish). Food chemistry 2002,79, 351-354.

2. Kondo, S., Kittikorn, M., Kanlayanarat, S., Preharvest antioxidant activities of tropical fruit and the effect of low temperature storage on antioxidants and jasmonates. Postharvest Biology and Technology 2005,36, 309-318.

3. Sulaiman, S. F., Yusoff, N. A. M., Eldeen, I. M., Seow, E. M., Sajak, A. A. B., Ooi, K. L., Correlation between total phenolic and mineral contents with antioxidant activity of eight Malaysian bananas (Musa sp.). Journal of Food Composition and Analysis 2011,24, 1-10.

4. Fatemeh, S., Saifullah, R., Abbas, F., Azhar, M., Total phenolics, flavonoids and antioxidant activity of banana pulp and peel flours: influence of variety and stage of ripeness. International Food Research Journal 2012,19, 1041.

5. Oyeyinka, B. O., Afolayan, A. J., Comparative and Correlational Evaluation of the Phytochemical Constituents and Antioxidant Activity of Musa sinensis L. and Musa paradisiaca L. Fruit Compartments (Musaceae). The Scientific World Journal 2020.

6. Pereira, A., Maraschin, M., Banana (Musa spp) from peel to pulp: ethnopharmacology, source of bioactive compounds and its relevance for human health. Journal of ethnopharmacology 2015,160, 149-163.

7. Padilla-Camberos, E., Flores-Fernández, J. M., Canales-Aguirre, A. A., Barragán-Álvarez, C. P., Gutiérrez-Mercado, Y., Lugo-Cervantes, E., Wound healing and antioxidant capacity of Musa paradisiaca Linn. peel extracts. Journal of Pharmacy \& Pharmacognosy Research 2016,4, 165-173.

8. Behiry, S. I., Okla, M. K., Alamri, S. A., El-Hefny, M., Salem, M. Z., Alaraidh, I. A., Ali, H. M., Al-Ghtani, S. M., Monroy, J. C., Salem, A. Z., Antifungal and antibacterial activities of Musa paradisiaca L. peel extract: HPLC analysis of phenolic and flavonoid contents. Processes 2019,7, 215.

9. Agama-Acevedo, E., Sañudo-Barajas, J., Vélez De La Rocha, R., González-Aguilar, G., Bello-Perez, L. A., Potential of plantain peels flour (Musa paradisiaca L.) as a source of dietary fiber and antioxidant compound. CyTA-Journal of Food 2016,14, 117-123.

10. Chang, C.-C., Yang, M.-H., Wen, H.-M., Chern, J.-C., Estimation of total flavonoid content in propolis by two complementary colorimetric methods. Journal of food and drug analysis 2002,10.

11. Marxen, K., Vanselow, K. H., Lippemeier, S., Hintze, R., Ruser, A., Hansen, U.-P., Determination of DPPH radical oxidation caused by methanolic extracts of some microalgal species by linear regression analysis of spectrophotometric measurements. Sensors 2007,7, 2080-2095.

12. Ermawati, D. E., Optimation Of Compostion Of Span 80-Croduret 50-Propylene Glycol As Emulsifier Of Strawberry Juice (Fragaria Vesca L.) Emulgel And Transport Test Through Shed Snake Skin Membrane. Journal of Food and Pharmaceutical Sciences 2016,4.

13. Campanini, M. Z., Custódio, D. L., Ivan, A. L. M., Martins, S. M., Paranzini, M. J. R., Martinez, R. M., Verri, W. A., Vicentini, F. T. M. C., Arakawa, N. S., de J. Faria, T., Baracat, M. M., Casagrande, R., 
Georgetti, S. R., Topical Formulations Containing Pimenta pseudocaryophyllus Extract: In Vitro Antioxidant Activity and In Vivo Efficacy Against UV-B-Induced Oxidative Stress. AAPS PharmSciTech 2014,15, 86-95; published online EpubFebruary 01 (10.1208/s12249-013-0049-8).

14. Sonia, N., Mini, C., Geethalekshmi, P., Vegetable peels as natural antioxidants for processed foods-a review. Agricultural Reviews 2016,37, 35-41.

15. Molyneux, P., The use of the stable free radical diphenylpicrylhydrazyl (DPPH) for estimating antioxidant activity. Songklanakarin J. sci. technol 2004,26, 211-219.

16. Shian, T. E., Abdullah, A., Antioxidant properties of three banana cultivars (Musa acuminata ‘Berangan','Mas' and 'Raja') extracts. Sains Malaysiana 2012,41, 319-324.

17. González-Montelongo, R., Lobo, M. G., González, M., Antioxidant activity in banana peel extracts: Testing extraction conditions and related bioactive compounds. Food Chemistry 2010,119, 1030-1039.

18. Georgetti, S. R., Casagrande, R., Vicentini, F. T. M.-d.-C., Verri Jr, W. A., Fonseca, M. J. V., Evaluation of the antioxidant activity of soybean extract by different in vitro methods and investigation of this activity after its incorporation in topical formulations. European Journal of Pharmaceutics and Biopharmaceutics 2006,64, 99-106.

19. Bernatoniene, J., Masteikova, R., Davalgiene, J., Peciura, R., Gauryliene, R., Bernatoniene, R., Majiene, D., Lazauskas, R., Civinskiene, G., Velziene, S., Topical application of Calendula officinalis (L.): Formulation and evaluation of hydrophilic cream with antioxidant activity. Journal of Medicinal Plants Research 2011,5, 868-877.

20. Mohsin, S., Akhtar, N., Mahmood, T., Khan, H., Mustafa, R., Formulation and stability of topical water in oil emulsion containing corn silk extract. Tropical Journal of Pharmaceutical Research 2016,15, $1115-1121$

21. Kuncari, E. S., Iskandarsyah, I., Praptiwi, P., Evaluasi, Uji Stabilitas Fisik dan Sineresis Sediaan Gel yang Mengandung Minoksidil, Apigenin dan Perasan Herba Seledri (Apium graveolens L.). Buletin Penelitian Kesehatan 2014,42, 213-222.

22. Shukr, M., Metwally, G. F., Evaluation of topical gel bases formulated with various essential oils for antibacterial activity against methicillin-resistant Staphylococcus aureus. Tropical Journal of Pharmaceutical Research 2013,12, 877-884.

23. Marquele-Oliveira, F., Fonseca, Y., De Freitas, O., Fonseca, M., Development of topical functionalized formulations added with propolis extract: stability, cutaneous absorption and in vivo studies. International journal of pharmaceutics 2007,342, 40-48

(C) 2019 by the authors. Submitted for possible open access publication under the terms and conditions of the Creative Commons Attribution (CC BY) license (http://creativecommons.org/licenses/by/4.0/). 